\title{
Prediction of Success Construction Claims by Construction Provider Due to Delays in Completion Work
}

\author{
Novera Meylinda ${ }^{1}$, Ayomi Dita Rarasati ${ }^{2}$ \\ novera.meylinda@ui.ac.id ${ }^{1}$, ayomi@ui.ac.id ${ }^{2}$ \\ Civil Engineering Department, University of Indonesia, Depok, Indonesia ${ }^{1,2}$
}

\begin{abstract}
To compete in the construction business, it is also necessary to be careful in seeing the opportunity for claims due to delays in completion work, especially for construction providers who often fail in filing claims. Most of the previous research on claims was more about predicting the appearance of claims. In fact, the claim that arises does not stop until it is accepted or not. So this research is conducted so that construction providers know how to make claims successful. We conducted a literature review and Decision tree method C4.5 to determine the order of success factors for claims from the most influential, and the research showed administration of claims is the most influential factor in the success of a claim so claim can be accepted and with a model accuracy of 81,29 .
\end{abstract}

Keywords: Claim, Prediction, Success factors, Decission tree, C4.5 algorithm.

\section{Introduction}

Delay in completion of work is one of the causes of claims and disputes. Delay in the completion of work is an almost common occurrence in a construction project, both private and government projects. For example, the delay that occurred in the Government's National Strategic Project (PSN). The Committee for the Acceleration of Priority Infrastructure (KPPIP) delivered 12 (twelve) PSN projects that were supposed to be completed by the end of 2019 but were postponed to 2020 [1]. The impact of delays is conflict and debate about what and who is the cause, also creates time demands, and added costs [2].

Claims for extention of time and additional cost or losses and expenses that submitted by construction providers often not optimal because of the position of construction users who are considered superior and construction providers are worried about getting bad reviews from clients and being seen as "claimants".

By knowing how claims can be accepted by construction users, judging from the success factors for claims, it will make the submission of claims made by construction providers more optimal. then a research is conducted on the prediction of the success of construction claims by construction providers due to delays in the completion of work.

The first research method used is a literature review to obtain the success factors for claims for work delays due to service users. To make a prediction model for claim success, the classification technique Decision Tree C4.5 is used, because it can convert data into decision rules. This decision tree can detail complex decision-making processes into simpler ones so that 
problem solutions can be more easily obtained and interpreted. Decision trees are used to solve a problem where each node is a decision and leaves are the solution to the problem [3]. A tree is a data structure consisting of nodes and edges [4]. The algorithm to build the decision tree is $\mathrm{C} 4.5$ which used gain ratio as splitting criteria. It begins from the root node which contains the entire dataset and than split by an atrtribute the forming nodes and edges which connecting the nodes. This process maintains recursively with the rules of splitting (goodness of cut up criterion) till the criteria are met. A node that isn't splitting anymore is referred to as a leaf node and classified with the majority class.

\section{Research Methods}

\subsection{Literature review}

Literature review is used to obtain the success factors for claims for work delays due to service users. Furthermore, validation is carried out with a validation questionnaire. The questionnaire contains responses from experts in the form of yes or no that the success factors for existing claims are in accordance with the success factors for each claim submission made.

\subsection{Decision tree $\mathbf{C} 4.5$}

Methods Data analysis with the decision tree algorithm C4.5 in this study is depicted in Fig. 1.

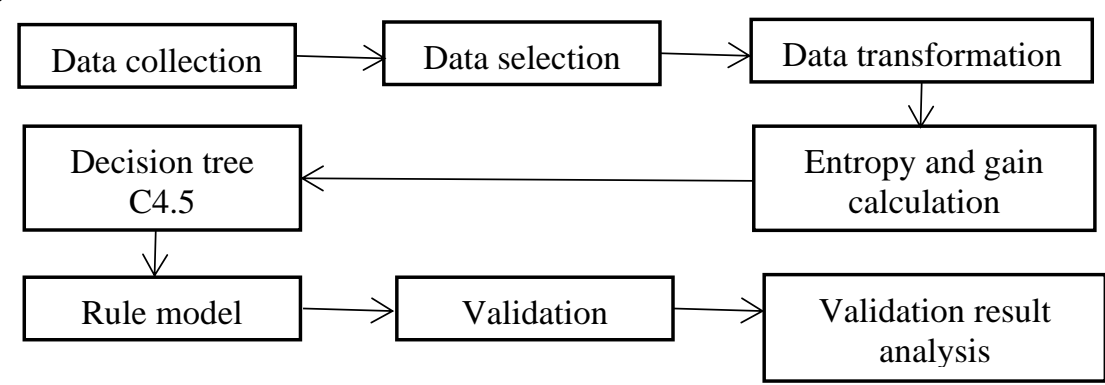

Fig 2. Research Procces Design

To find out the gain ratio, first calculate the entropy, entropy is used to determine how informative the attribute is. $\mathrm{S}$ is the Set of Cases, $\mathrm{n}$ is the number of partitions $\mathrm{S}$. and pi is the number of cases on partition $\mathrm{i}$. It is given by equation (1).

Entopy $(\mathrm{S})=\sum_{i=0}^{n}-p i * \log _{2} p i$

After knowing the entropy, then calculate the information gain. $\mathrm{S}$ is the Set of Cases, $\mathrm{n}$ is the number of partitions atribute $\mathrm{A},|\mathrm{Si}|$ is the number of cases on partition $i$, and $|S|$ is the number of cases in $S$. It is given by equation (2).

$\operatorname{Gain}(S, A)=\operatorname{Entropy}(S)-\sum_{i-1}^{n} \frac{|S i|}{|S|} * \operatorname{Entropy}(S i)$

To determine the root node with the $\mathrm{C} 4.5$ algorithm, the largest value of the gain ratio will be used, because the gain ratio can provide a more specific value than the gain or 
information gain. However, it is necessary to first calculate the split information with the equation (3).

SplitInfo $(S, A)=\sum_{i=1}^{c}-\frac{S_{i}}{S} \log _{2} \frac{S_{i}}{S}$

Gain Ratio formula is found in equation (4), as follows.

Gain ratio $=\frac{\operatorname{Gain}(S, A)}{\operatorname{SplitInfomation}(S, A)}$

The gain in equation is the result of calculating the Information gain obtained after calculating the Entropy. Then select the gain ratio that produces the best practitioner or the greatest value to then be used as the root node in the $\mathrm{C} 4.5$ decision tree.

\subsection{Model validation with $k$-cross validation}

Model validation with k-fold Cross Validation is a technique to ensure that the results found in the analysis can be generalized to an independent and invisible data set. This study uses 2 fold cross validation because of the small amount of the data. In two-fold cross-validation the data is partitioned into independent and similar subsets and using random assignment into the training data set and the test data set. The model is then constructed using data from the $\mathrm{k}$ 1 subset, using the data subset as the test set. This is done iteratively until we have k different models, see Figure 2. The results from the $\mathrm{k}$ models are then combined using the average or selecting.

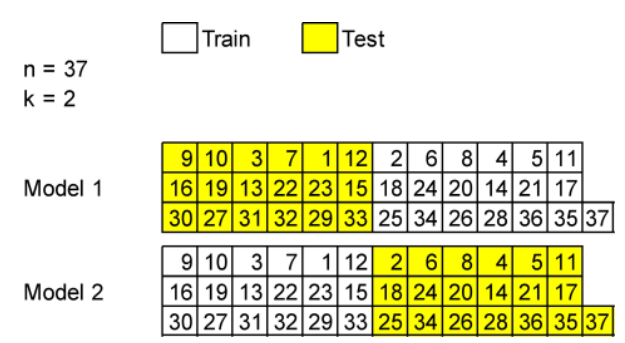

Fig 2. Splitting research data by 2 fold cross validation

In cross-validation $\mathrm{k}=2$, the data set is randomly generated and then divided into two sets ( $\mathrm{d} 0$ and $\mathrm{d} 1$ ), so that both sets have the same size. Then training will be carried out on $\mathrm{d} 0$ and validation on $\mathrm{d} 1$, followed by training on $\mathrm{d} 1$ and validating on $\mathrm{d} 0$.

Performance measure is very important to indicate how well the model classifies information. In general, the confusion matrix table as in Table one is usedwhen verity values are notable to judge the model performance on a group of take a look at data [4]. Model performance is measured by conniving the worth of accuracy.

Table 1. Confusion matrix

\begin{tabular}{cccc}
\hline & & \multicolumn{2}{c}{ Predicted } \\
& & Negative & Positive \\
\hline Actual & Positive & False Negative (FN) & True Positive (TP) \\
& Negative & True Negative (TN) & False Positive (FP) \\
\hline
\end{tabular}




$$
\text { Accuracy }=\frac{T P+T N}{T P+F P+T N+F N}
$$

Accuracy is obtained by calculated verity foreseen observation divided by total observations. exactness additionally called positive predicted values is obtained by calculated the true predicted positive observations divided by total predicted positive observations.

\section{Result and Discussion}

\section{Success factors for construction claims by construction providers due to delays in completing work}

The questionnaire contains the success factors of claims based on previous research references which are then verified whether these claim success factors can be used as a reference to determine the prediction of the success of construction claims by service providers due to delays in completing work. The results of the recapitulation of phase 1 data collection can be seen in Table 2 .

Table 2. Recapitulation of validation of construction claim success factors

\begin{tabular}{|c|c|c|c|c|c|}
\hline No. & Claim success factor & $\mathrm{P} 1$ & $\mathrm{P} 2$ & P3 & Status \\
\hline 1. & $\begin{array}{l}\text { Does the submission of the claim state the claim requested (its } \\
\text { rights and compensation) }\end{array}$ & Y & $\mathrm{Y}$ & $\mathrm{Y}$ & $\sqrt{ }$ \\
\hline 2. & What is cause of the claim & Y & Y & Y & $\sqrt{ }$ \\
\hline 3. & Complete or not the details of the claim & Y & Y & $\mathrm{Y}$ & $\sqrt{ }$ \\
\hline 4. & Complete or not the evidence for each claim & Y & $\mathrm{Y}$ & $\mathrm{Y}$ & $\sqrt{ }$ \\
\hline 5. & $\begin{array}{l}\text { Is the claims analysis appropriate on a contractual/legal } \\
\text { basis/based on evidence }\end{array}$ & $\mathrm{Y}$ & $\mathrm{Y}$ & $\mathrm{Y}$ & $\sqrt{ }$ \\
\hline 6. & Is there any prior notification of the submitted claim & $\mathrm{Y}$ & $\mathrm{Y}$ & $\mathrm{Y}$ & $\sqrt{ }$ \\
\hline 7. & Complete or not Project documentation & $\mathrm{Y}$ & Y & Y & $\sqrt{ }$ \\
\hline 8. & Complete or not Project administration & $\mathrm{Y}$ & Y & Y & $\sqrt{ }$ \\
\hline 9. & Persuasive presentation & $\mathrm{Y}$ & Y & $\mathrm{Y}$ & $\sqrt{ }$ \\
\hline 10 & $\begin{array}{l}\text { How does the submission document explain the cause } \\
\text { and effect of the claim }\end{array}$ & Y & Y & Y & $\sqrt{ }$ \\
\hline 11. & $\begin{array}{l}\text { Relationship between Construction Providers and } \\
\text { Construction Users }\end{array}$ & $\mathrm{Y}$ & Y & Y & $\sqrt{ }$ \\
\hline 12. & Significance and criticality of claims & $\mathrm{Y}$ & $\mathrm{Y}$ & $\mathrm{Y}$ & $\sqrt{ }$ \\
\hline
\end{tabular}




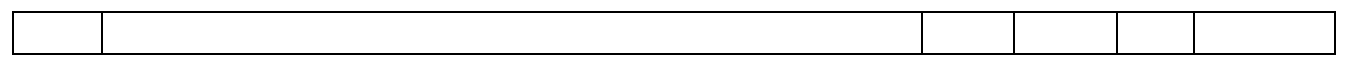

Based on the results of data collection on the factors that affect the success of claims, all of these factors can be used to determine the prediction of the success of construction claims by construction providers due to delays in completing work. Of the 12 (twelve) factors that influence the success of the above claims, there are two factors that are difficult to measure, namely the relationship between construction providers and construction users and the significance and criticality of claims. Based on discussions with experts, the relationship between construction providers and construction users will be measured by the number of projects that have been worked on together, see Tabel 3.

Table 3. Construction provider and construction user relationship category table

\begin{tabular}{|c|c|}
\hline $\begin{array}{c}\text { The number of projects working } \\
\text { together }\end{array}$ & $\begin{array}{c}\text { Relationship between construction } \\
\text { provider and construction user }\end{array}$ \\
\hline$>2$ projects & good \\
\hline $1-2$ projects & enough \\
\hline
\end{tabular}

Meanwhile, the significance and criticality of claims are measured by the value claimed compared to the value of the construction contract, and also the amount of time claimed compared to the implementation period based on the contract. However, the significance and criticality of claims cannot be assessed only in one claim submission, because if there are further claims then the number can be large and significant, so that the construction provider always considers the claimed value to be significant and the time claimed is considered critical because it has exceeded the planned completion time

\section{Decision tree model predicts the success of claims by construction providers due to delays in completing work}

Each claim submission is identified the cause of the delay in completing its work to find out if the delay is caused by the construction user. Claims submitted include extention time and additional costs that follow which are submitted separately or submitted all at once in one submission. Each claim submission is carried out by collecting data according to the factors that affect the success of claims obtained in the previous data processing. The 37 data collected can be seen in Table 4.

Furthermore, calculations are carried out using the entropy, gain, split Information and gain ratio formulas for each attribute as follows :

Number of data $=37$

Accepted $=20$

Not Accepted $=17$

Then the value ofi entropy $(S)=((-20 / 37) * \log 2(20 / 37)+(-17 / 37) * \log 2(17 / 37))$

$$
\begin{aligned}
& =(-0,541 *-0,888)+(-0,459 *-1,122) \\
& =0,47974339+0,51550916 \\
& =0,995252549
\end{aligned}
$$

and the calculation is continued with microsoft excel, see Table 5. 
Table 4. Data on submission of claims by contractor providers along with factors that affect the success of claims

\begin{tabular}{|c|c|c|c|c|c|c|c|}
\hline $\begin{array}{l}\text { Code } \\
\text { of } \\
\text { claim }\end{array}$ & $\begin{array}{l}\text { Submission } \\
\text { Document } \\
\text { Submission } \\
\text { states the } \\
\text { claim } \\
\text { requested (its } \\
\text { rights and } \\
\text { compensation) }\end{array}$ & $\begin{array}{l}\text { Claim } \\
\text { Details }\end{array}$ & $\begin{array}{c}\text { Evidence } \\
\text { of each } \\
\text { claim }\end{array}$ & $\begin{array}{l}\text { Claim } \\
\text { for } \\
\text { each } \\
\text { cause } \\
\text { of } \\
\text { claim }\end{array}$ & $\begin{array}{l}\text { Eleme } \\
\text { nt of } \\
\text { claim } \\
\text { cost }\end{array}$ & $\begin{array}{c}\text { Analysis of } \\
\text { claims based } \\
\text { on } \\
\text { contract/law/w } \\
\text { ith evidence }\end{array}$ & $\begin{array}{c}\text { The } \\
\text { terms/conditio } \\
\text { ns of the } \\
\text { claim have } \\
\text { been met }\end{array}$ \\
\hline $\mathbf{a}$ & b & c & d & e & $\mathbf{f}$ & g & $\mathbf{h}$ \\
\hline G1 & Y & $\mathrm{Y}$ & complete & $\begin{array}{l}\text { Time } \\
\& \text { cost }\end{array}$ & prelim & Y & Not listed \\
\hline G2 & $\mathrm{Y}$ & $\mathrm{Y}$ & complete & time & $\mathrm{N}$ & $\mathrm{Y}$ & $\mathrm{Y}$ \\
\hline G3 & $\mathrm{Y}$ & $\mathrm{Y}$ & complete & cost & $\mathrm{N}$ & $\mathrm{N}$ & Not listed \\
\hline G4 & $\mathrm{Y}$ & $\mathrm{Y}$ & complete & time & $\mathrm{N}$ & $\mathrm{Y}$ & $\mathrm{Y}$ \\
\hline G5 & Y & $\mathrm{Y}$ & complete & Cost & $\begin{array}{l}\text { Over- } \\
\text { head }\end{array}$ & $\mathrm{N}$ & $\mathrm{N}$ \\
\hline$\ldots$ & $\ldots$ & $\ldots$ & $\ldots$ & $\ldots$ & $\ldots$ & $\ldots$ & $\ldots$ \\
\hline G37 & & & & & & & \\
\hline
\end{tabular}

Table 4. (cont.)

\begin{tabular}{|c|c|c|c|c|c|c|c|c|}
\hline $\begin{array}{l}\text { Code } \\
\text { of } \\
\text { claim }\end{array}$ & $\begin{array}{c}\text { Claim } \\
\text { notif }\end{array}$ & $\begin{array}{l}\text { Project } \\
\text { doc. }\end{array}$ & $\begin{array}{l}\text { Project } \\
\text { adm. }\end{array}$ & $\begin{array}{l}\text { Persuasi } \\
\text { ve } \\
\text { presentat } \\
\text { ioa }\end{array}$ & $\begin{array}{l}\text { Explaini } \\
\text { ng cause } \\
\text { and } \\
\text { effect of } \\
\text { claim }\end{array}$ & $\begin{array}{l}\text { Contractor } \\
\text { relationship } \\
\text { with Owner }\end{array}$ & $\begin{array}{l}\text { Significant } \\
\text { claim }\end{array}$ & $\begin{array}{c}\text { Claim } \\
\text { accepted }\end{array}$ \\
\hline $\mathbf{a}$ & $\mathbf{i}$ & $\mathbf{j}$ & $\mathbf{k}$ & 1 & $\mathbf{m}$ & $\mathbf{n}$ & o & p \\
\hline G1 & $\mathrm{Y}$ & complete & complete & $\mathrm{Y}$ & $\mathrm{Y}$ & enough & $Y$ & $\mathrm{Y}$ \\
\hline G2 & $\mathrm{Y}$ & complete & complete & $\mathrm{N}$ & $\mathrm{Y}$ & enough & $\mathrm{Y}$ & $\mathrm{Y}$ \\
\hline G3 & $\mathrm{N}$ & complete & complete & $\mathrm{N}$ & $\mathbf{N}$ & enough & $\mathrm{Y}$ & $\mathrm{N}$ \\
\hline G4 & $\mathrm{Y}$ & complete & complete & $\mathrm{Y}$ & $\mathrm{Y}$ & enough & $\mathrm{Y}$ & $\mathrm{Y}$ \\
\hline G5 & $Y$ & complete & complete & $Y$ & $Y$ & enough & $\mathrm{Y}$ & $\mathrm{N}$ \\
\hline$\ldots$ & $\ldots$ & $\ldots$ & $\ldots$ & $\ldots$ & $\ldots$ & $\ldots$ & $\ldots$ & $\ldots$ \\
\hline G37 & & & & & & & & \\
\hline
\end{tabular}


Table 5. Calculation of the value of entropy, information gain, split information, and gain ratio for each attribute to determine the root node.

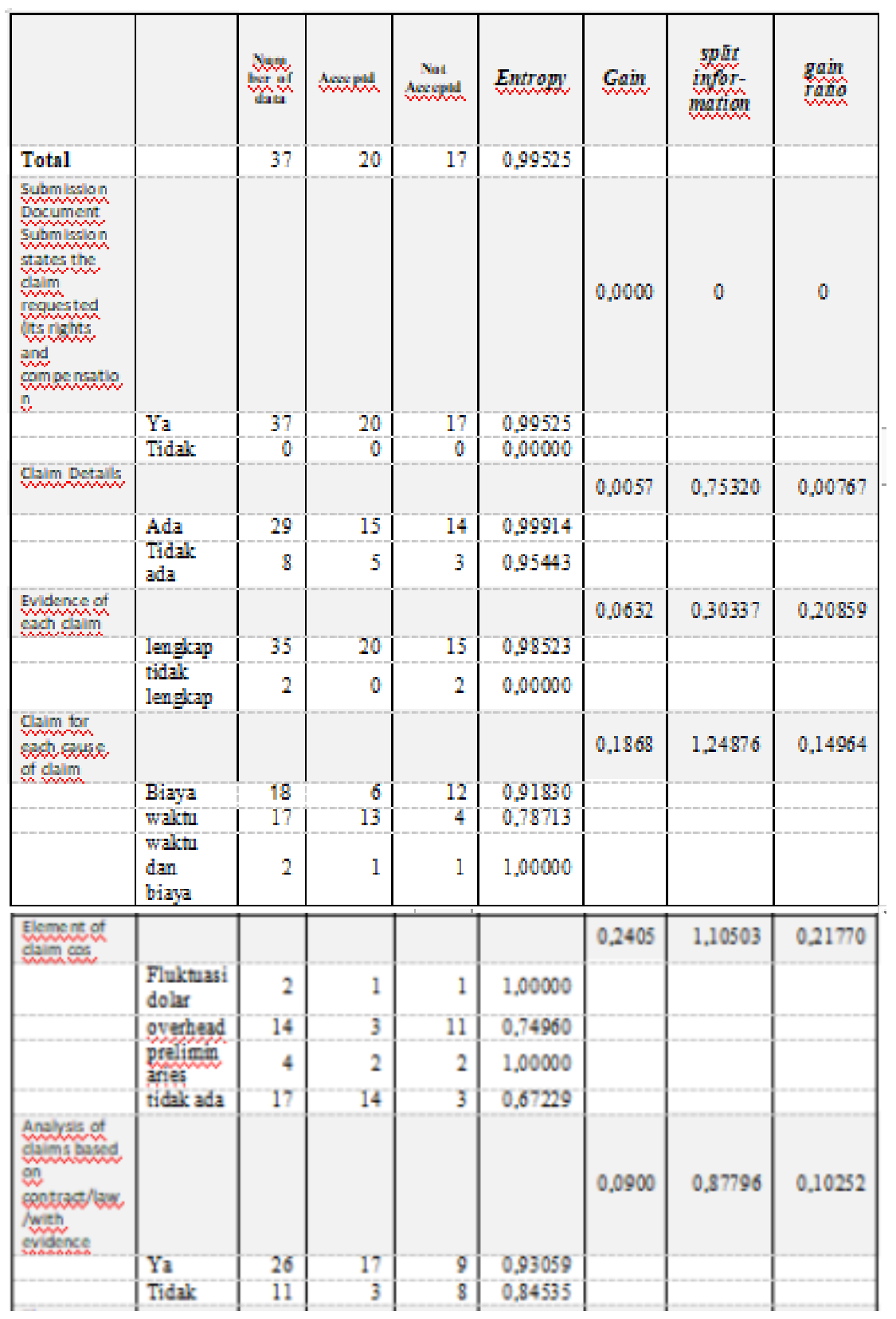


Table 5. (cont.)

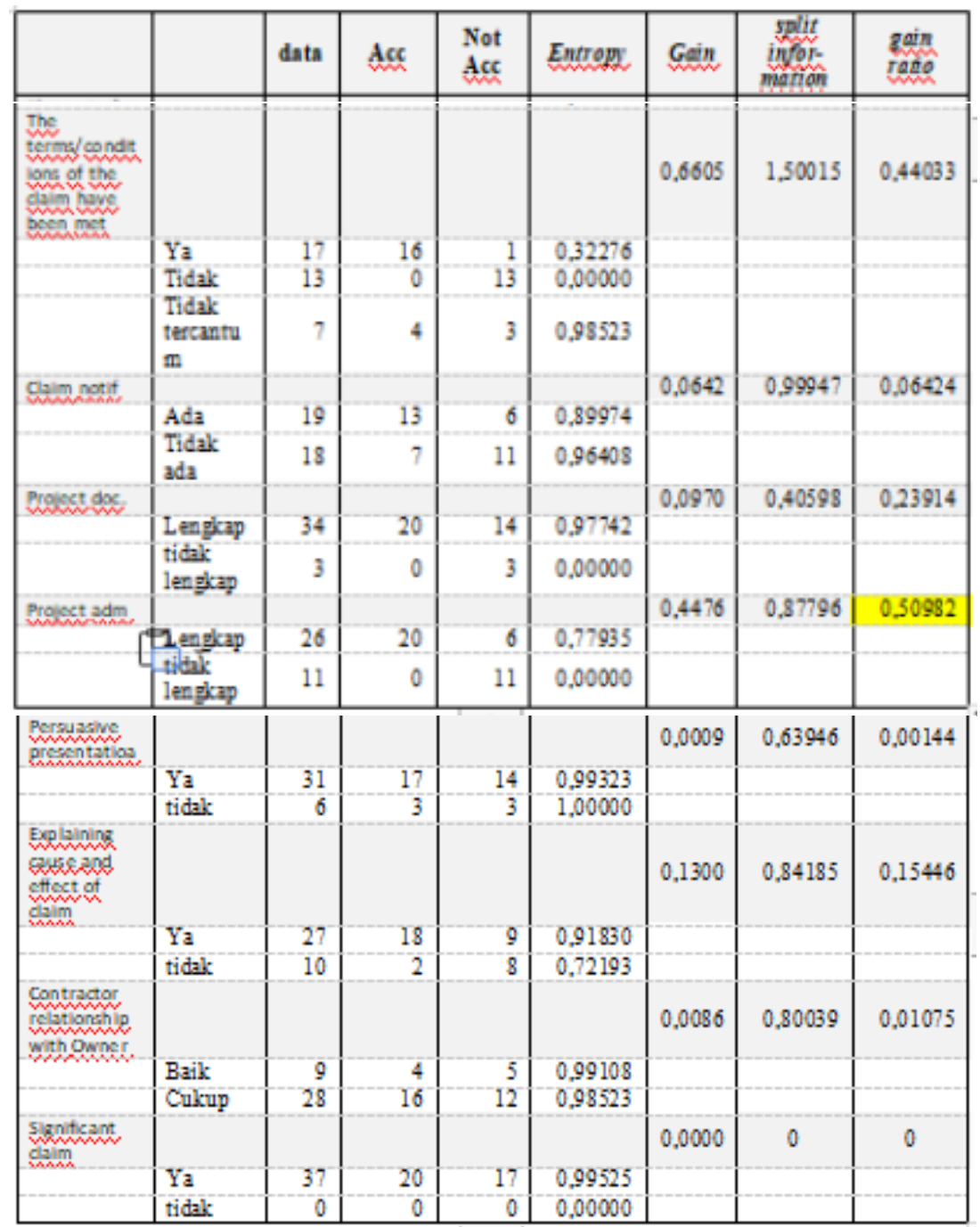

From the results of the calculation of the data table, it is known that the attribute with the highest gain ratio is "claims administration" which is 0.50982. Thus the attribute "Administration claims" can be a root node. There are 2 values for the "Claim administration" attribute, namely "Complete" and "incomplete". The attribute value "incomplete" has classified the claim submission data as rejected so that no further calculations are needed, but for the attribute value "Claim administration" "yes" further calculations need to be carried out.

The decision tree formation process stops because all data records in the last node have got the same class, there are no record attributes that can be partitioned again and no records in the branch are empty. So that the final decision tree based on manual calculations can be described as on Figure 3. 


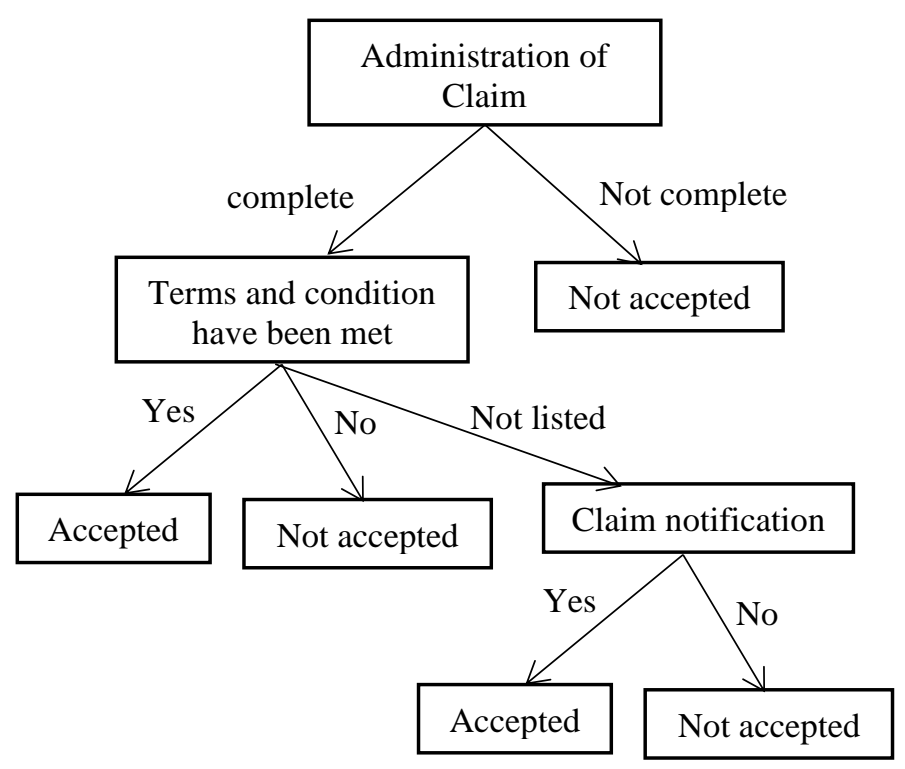

Fig 3. Decision tree model predicts the success of claims by construction providers due to delays in completing work

\section{Model validation}

Tabel 6. Confusion Matrix decision tree with 2-fold cross validation

\begin{tabular}{|l|l|l|}
\hline & true Diterima & true Ditolak \\
\hline pred. Diterima & 20 & 7 \\
\hline pred. Ditolak & 0 & 10 \\
\hline
\end{tabular}

From Table 6 can be explained that the number of data is 27 where 20 claim submissions are predicted correctly (true positive / TP) that the claim can be accepted, while 7 claims submissions are predicted incorrectly (false positive / FP) by the decision tree classifier C4.5, where in fact the submission of the claim was rejected. Tests on the submission of claims that are predicted to be rejected show that 10 claim submissions (true negative / TN) are correctly recognized that the claim submission is rejected, and no claim submissions are received according to the prediction (false negative / FN). So that the values of accuracy, precision, and recall are $81.29 \%, 100 \%$, and $59.72 \%$, respectively.

\section{Conclution}

Rules for accepted claims: 1) If the claim administration is complete and the claim terms/conditions have been met, the claim is accepted. 2) If the claim administration is complete, 
the terms/conditions of the claim have been fulfilled not stated in the contract/law, there is a claim notification then the claim is accepted

Rules for rejected claims: 1) If the claim administration is incomplete then the claim is rejected.

2) If the claim administration is complete, the terms/conditions of the claim do not meet the requirements in the contract/law, then the claim is rejected. 3) If the claim administration is complete, the terms/conditions of the claim have been fulfilled not stated in the contract/law, there is no claim notification then the claim is rejected. Decision Tree C4.5 method can be implemented to predict the success of claim submission by service providers to service users with an accuracy rate of $81.29 \%$.

\section{References}

[1] (n.d.). Retrieved from https://www.cnnindonesia.com/ekonomi/20191228165920-92460687/penyelesaian-12-proyek-strategis-nasional-molor-ke-2020

[2] David, M. W. P. : Evaluation- From Precision, Recall and F-Factor to ROC, Informedness, Markedness and Correlation. Australia: School of Informatics and Engineering Flinders University of South Australia. 2007

[3] C. J. Mantas, J. Abellán, Francisco Javier García Castellano. Analysis of Credal-C4.5 for classification in noisy domains. Mathematics, Computer Science Expert Syst. Appl. 2016

[4] Proboyo, B. Keterlambatan Waktu Pelaksanaan Proyek : Klasifikasi Dan Peringkat Dari Penyebab-Penyebabnya, Dimensi Teknik Sipil. 1999. Vol. 1 No. 2

[5] Ghozali, M. Ferdi. Penggunaan Decision Tree Analysis dalam Perencanaan Bisnis. Institut Teknologi Bandung. 2017.

[6] Hermawati, F. A. Data Mining. Yogyakarta: Penerbit Andi. 2013. 